(c) American Dairy Science Association, 2004.

\title{
The Influence of Treatment with Dual Purpose Bacterial Inoculants or Soluble Carbohydrates on the Fermentation and Aerobic Stability of Bermudagrass*
}

\author{
A. T. Adesogan, N. Krueger, M. B. Salawu, D. B. Dean, and C. R. Staples \\ Department of Animal Sciences, \\ University of Florida, Gainesville 32611
}

\section{ABSTRACT}

This study determined the effectiveness of an inoculant (BB), molasses, or a mixture of either BB and molasses (BBM) or BB and fibrolytic enzymes (BBE) for improving the fermentation and aerobic stability of bermudagrass. A 6-wk regrowth of Tifton 85 bermudagrass was conserved in quadruplicate mini silos alone or after treatment application. The inoculant contained a mixture of $P$. pentosaceus $12455,1 \times 10^{5} \mathrm{cfu} / \mathrm{g}$ of fresh forage, L. buchneri $40788,4 \times 10^{5} \mathrm{cfu} / \mathrm{g}$ of fresh forage, and beta-glucanase, alpha-amylase, and xylanase; BBE contained similar bacteria and enzymes as BB, but greater enzyme activities. Chemical composition was quantified after $2,4,7,30$, and $60 \mathrm{~d}$ of ensiling. Microbial composition and aerobic stability were measured after $60 \mathrm{~d}$ of ensiling, at which point the $\mathrm{pH}$ of additivetreated silages was consistently lower and DM recovery was higher than in untreated silages. The BB, BBM, and molasses-treated silages had less ammonia $\mathrm{N}$ than untreated silages, and $\mathrm{BB}, \mathrm{BBM}$, and $\mathrm{BBE}$-treated silages had less residual water-soluble carbohydrates than untreated silages. All silages had high acetic acid $(47.5 \mathrm{~g} / \mathrm{kg} \mathrm{DM})$ and low lactic acid $(1.7 \mathrm{~g} / \mathrm{kg} \mathrm{DM})$ concentrations. However, untreated and BBE-treated silages had more butyric acid and ammonia $\mathrm{N}$, suggesting that a clostridial fermentation had occurred. These butyric forages were more aerobically stable $(27 \mathrm{~d})$ but less desirable for feeding than those ensiled with BB or molasses, which were stable for $6.9 \mathrm{~d}$. In conclusion, $\mathrm{BB}$ and molasses treatments improved the digestibility and fermentation of bermudagrass and produced higher quality silages that were stable for $6.9 \mathrm{~d}$. Mixing BB with molasses or the inoculant tested was not more beneficial than $\mathrm{BB}$ or molasses alone.

Received February 23, 2004

Accepted June 9, 2004.

Corresponding author: A. T. Adesogan; e-mail: adesogan@animal. ufl.edu.

*This research was supported by the Florida Agriculture Experiment Station, and approved for publication as Journal Series No. R-10391.
(Key words: Lactobacillus buchneri, aerobic stability, inoculant, molasses)

Abbreviation key: $\mathbf{B B}=$ a mixture of Pediococcus pentosaceus $12455,1 \times 10^{5} \mathrm{cfu} / \mathrm{g}$ of fresh forage, Lactobacillus buchneri $40788,4 \times 10^{5} \mathrm{cfu} / \mathrm{g}$ of fresh forage, and beta-glucanase, alpha-amylase, and xylanase, BBE = $\mathrm{BB}$ plus additional beta-glucanase, alpha-amylase, and xylanase, $\mathbf{B B M}=\mathrm{BB}$ plus molasses, $\mathbf{L A B}=$ lactic acid bacteria, $\mathbf{W S C}=$ water-soluble carbohydrates.

\section{INTRODUCTION}

Traditionally, silage inoculants were developed for the purpose of reducing proteolysis and curtailing losses of DM and water-soluble carbohydrates (WSC) during fermentation. Consequently, such inoculants contained numerous homofermentative, acidophilic bacteria that would dominate the epiphytic bacterial population and direct the fermentation along the homolactic pathway. Treatment with these inoculants improved the efficiency of the fermentation process and enhanced the quality of the silage. However, the resulting silage was sometimes more susceptible to aerobic deterioration at feedout, such that considerable losses of DM and desirable nutrients could occur eventually. This led to the development of inoculants that were aimed solely at improving the aerobic stability of silages. Lactobacillus buchneri has achieved the most widespread use for this purpose. Treatment with L. buchneri inoculants has improved the aerobic stability of several forages (Ranjit and Kung, 2000; Driehuis et al., 2001; Kung and Ranjit, 2001; Adesogan et al., 2003). However, L. buchneri is heterofermentative; consequently, increased losses of WSC can occur during the fermentation of forages treated with L. buchneri inoculants. This has led to the recent development of 'dual purpose' inoculants containing a mixture of homofermentative and heterofermentative lactic acid bacteria $(\mathbf{L A B})$ that are aimed at improving the efficiency of the anaerobic fermentation and aerobic feedout phases of silage production, respectively. Because of the novelty of these inoculants, relatively few studies have investigated their effectiveness. 
Adesogan and Salawu (2004) found that such inoculants improved the fermentation of pea wheat intercrops but did not improve their aerobic stability. In contrast, other studies (Driehuis et al., 2001; Weinberg et al., 2002; Filya, 2003a,b) found that such inoculants increased the fermentation and aerobic stability of ryegrass. These dual-purpose inoculants have never been tested on tropical forages, which typically have low WSC concentrations and, therefore, follow a heterolactic, acetate-dominated fermentation pathway. Umana et al. (1991) showed that an inoculant containing homolactic bacteria enhanced the quality of bermudagrass silage when it was supplemented with molasses. In contrast, Kunkle et al. (1988) stated that, over several studies, homolactic bacteria consistently improved the fermentation of bermudagrass, although they did not always improve DM recovery. The objective of this study was to determine the effect on the fermentation and aerobic stability of bermudagrass silage of 1 ) a dual purpose inoculant, 2) supplemental soluble carbohydrates from molasses, 3) a mixture of the dual purpose inoculant and molasses, and 4) a mixture of the dual purpose inoculant and cellulase and hemicellulase enzymes. The rationale for including treatments 3 and 4 was to determine whether the WSC concentration in the bermudagrass was sufficient for optimizing the fermentation in the presence or absence of the inoculant.

\section{MATERIALS AND METHODS}

\section{Silage Production}

A 6-wk regrowth of Tifton 85 bermudagrass was harvested from the University of Florida Santa Fe Beef Unit at $1000 \mathrm{~h}$ on July 11, 2003, with a rotary disc mower. To reduce the moisture that had accumulated in the forage because of rain during the harvest, the forage was spread out on a tarp, air-dried using a ventilation fan, and wilted for $3 \mathrm{~h}$. The wilted forage was chopped to 3-cm lengths with a forage chopper (Azteca Picadore SHP; Central Campesina, Merida, Mexico). Chopped forages were conserved 1) without treatment or after treatment with 2) a mixture of Pediococcus pentosaceus 12455 ( $1 \times 10^{5} \mathrm{cfu} / \mathrm{g}$ of fresh forage), $L$. buchneri $40788\left(4 \times 10^{5} \mathrm{cfu} / \mathrm{g}\right.$ fresh forage), and hydrolytic polysaccharases (BB; Lallemand Animal Nutrition, Milwaukee, WI); 3) $50 \mathrm{~g} / \mathrm{kg}$ of DM of standard blackstrap sugar cane molasses, which contained extra water to reduce viscosity (United States Sugar Corp., Clewiston, FL); 4) a mixture of BB and molasses treatments (BBM); and 5) a mixture of BB and an enzyme complex (BBE) containing additional hydrolytic polysaccharase activity. Lallemand Animal Nutrition stipulated the microbial counts in the inoculants that are mentioned previously and indicated that the enzymes in $\mathrm{BB}$ and $\mathrm{BBE}$ were beta-glucanase, alpha-amylase, and xylanase. The respective stipulated enzyme activities of BB were 3.44 and $1.72 \mathrm{mg}$ of glucose/min per $\mathrm{kg}$ of fresh forage and $1.87 \mathrm{mg}$ of xylose/min per $\mathrm{kg}$ of fresh forage; those for BBE were 6.87 and $3.44 \mathrm{mg}$ of glucose/ min per $\mathrm{kg}$ of fresh forage and $3.73 \mathrm{mg}$ of xylose/min per $\mathrm{kg}$ of fresh forage, respectively. The molasses contained $750 \mathrm{~g}$ of DM $/ \mathrm{kg}, 50 \mathrm{~g} / \mathrm{kg}$ of CP, and $423 \mathrm{~g} / \mathrm{kg}$ of WSC. The additives were dissolved in $50 \mathrm{~mL}$ of deionized water and sprayed in a fine mist on $50 \mathrm{~kg}$ of forage. A similar quantity of deionized water was sprayed on the untreated forages. Representative samples (about $4 \mathrm{~kg}$ ) of the treated, unensiled forages were frozen for subsequent laboratory analysis. Four replicates of each of the untreated or treated forages were weighed $(1.2 \mathrm{~kg})$ into a plastic bag and placed in four 2.8-L polyvinyl chloride cylindrical mini silos to give a total of 20 silos for all treatments. To allow monitoring of the fermentation pattern over time, 20 silos were prepared for opening after 2, 4, 7, and $30 \mathrm{~d}$ of ensiling, such that a total of 80 mini silos were prepared. In addition, $5-\mathrm{kg}$ untreated or treated forage samples were weighed into plastic bags within 4 replicate 20 -L plastic macro silos per treatment to give a total of 20 macro silo samples that would be opened after $60 \mathrm{~d}$ of ensiling. The forage within the bags was consolidated manually to expel air and to ensure a packing density of at least $250 \mathrm{~kg} / \mathrm{m}^{3}$. The actual densities achieved were 250 and $428 \mathrm{~kg} / \mathrm{m}^{3}$ for the macro and mini silos, respectively. The bags were secured tightly with plastic ties, and the mini and macro silos were sealed immediately using drain test plugs and plastic covers, respectively. Weights of the empty and full silos were recorded, and silos were subsequently stored at ambient temperature $\left(18\right.$ to $\left.28^{\circ} \mathrm{C}\right)$ in a covered barn.

At silo opening, final silo weights were recorded, and approximately $100 \mathrm{~g}$ of silage from the top of each silo were discarded to eliminate the slightly moldy material at the top of silos. The remaining silage in each bag was mixed and subsequently subsampled for DM determination $(200 \mathrm{~g})$, silage juice extraction $(200 \mathrm{~g})$, chemical analysis $(200 \mathrm{~g})$ and long-term storage $\left(-20^{\circ} \mathrm{C} ; 200\right.$ g). In addition, forages that were ensiled for $60 \mathrm{~d}$ in macro silos were subsampled for microbial enumeration $(200 \mathrm{~g})$ and aerobic stability (1.5 kg). Samples destined for microbial analysis were heat-sealed within gas impermeable bags (Kapak Scotch Pak; Kapak Corp., Minneapolis, MN), placed on ice, and dispatched on the same day to the American Bacteriological \& Chemical (ABC) Research Corp. (Gainesville, FL).

\section{Laboratory Analysis}

Twenty grams of the silage or freshly treated, unensiled forage were homogenized for $30 \mathrm{~s}$ in a blender 
with $200 \mathrm{~mL}$ of deionized water. The resulting suspension was filtered through 4 layers of cheesecloth and centrifuged for $20 \mathrm{~min}$ at $27,500 \times g$; the pellet was then discarded. Samples of the supernatant were reserved for subsequent WSC, ammonia $\mathrm{N}$, and $\mathrm{pH}$ analysis. The $\mathrm{pH}$ was measured using a $\mathrm{pH}$ meter (Corning model 12; Corning Scientific Instruments, Medfield, MA). The DM of fresh samples and silage samples was determined in a forced-draft oven set at $60^{\circ} \mathrm{C}$ for 48 h. Dry matter recovery was estimated by measuring differences between the product of silo weight and forage DM concentration before and after ensiling. Ash was determined in a muffle furnace at $500^{\circ} \mathrm{C}$ for $5 \mathrm{~h}$. The WSC were measured using the anthrone reaction assay (Ministry of Agriculture, 1986). Ammonia N was determined using an adaptation for the Technicon Auto Analyzer of the Noel and Hambleton (1976) Kjeldahl method.

The following additional analyses were conducted on forages prior to ensiling and silages that had been ensiled for $60 \mathrm{~d}$. Both NDF and ADF were determined using the methods of Van Soest et al. (1991). The NDF was determined using Method A without the amylase step, and the ash-free results were expressed on a DM basis. Crude protein was calculated by multiplying Kjeldahl N estimates (AOAC, 1990) by 6.25, and in vitro digestibility was determined using the Tilley and Terry (1963) method. In addition, 200-g samples of each replicate of silages ensiled for $60 \mathrm{~d}$ were dispatched on ice to Dairyland Laboratories, Inc. (Sauk Rapids, MN) for analysis of lactic acid, VFA, ethanol, and CP; VFA, ethanol, and lactic acid were determined by high performance liquid chromatography (Muck and Dickerson, 1988). Yeasts, molds, and LAB were enumerated at the American Bacteriological \& Chemical (ABC) Research Corporation. Serial dilutions up to $1 \times 10^{10}$ were made using $25 \mathrm{~g}$ of silage and Butterfields phosphate buffer. Lactic acid bacteria were enumerated by pour plating in Elliker agar using the method of Downes and Ito (2001). Plates were incubated aerobically at $30^{\circ} \mathrm{C}$ for 3 d. Yeast and molds were enumerated by pour plating in Standard Methods (M124) agar to which $40 \mathrm{ppm}$ of chloramphenicol and chlortetracycline were added (Tournas et al., 1999). Plates were incubated aerobically at $25^{\circ} \mathrm{C}$ for $5 \mathrm{~d}$. Aerobic stability was measured in quadruplicate, using data loggers that recorded hourly temperature readings from thermocouple wires placed at the center of a bag containing $1 \mathrm{~kg}$ of silage within an open-top polystyrene box. The boxes were covered with 2 layers of cheesecloth to minimize drying and stored at room temperature $\left(21\right.$ to $\left.25^{\circ} \mathrm{C}\right)$ for $27 \mathrm{~d}$. Aerobic deterioration was denoted by a $2^{\circ} \mathrm{C}$ rise above room temperature. To verify the accuracy of the temperature readings, one wireless, digital temperature sensor (HA-
9 Point Sensor Temperature; Point Six Wireless, Lexington, KY) was placed in each of the silages in the polystyrene boxes. These temperature sensors contained a built-in microprocessor and a radio transmitter that sends radio frequency signals to a Point Server (Point Six Wireless) that processes the data and makes it available to be queried at a remote location. The Point Server was set to download hourly temperature recordings received from the Point sensors for $29 \mathrm{~d}$. The DM change of the silages during the aerobic phase was monitored by subtracting the product of the silo weights and silo DM concentrations at silo opening from that obtained $29 \mathrm{~d}$ later.

\section{Statistical Analyses}

The effect of the additives on fermentation and nutritive value indices in forages that were freshly treated or opened at each stage of ensiling were determined separately by ANOVA using a completely randomized design. The analyses were carried out using the General Analyses of Variance directive within the Genstat statistical package (Genstat V, 1997). Significance was declared at the $5 \%$ level, and tendencies were declared at the $10 \%$ level. Degrees of freedom for treatment were partitioned into preplanned contrasts including untreated vs. BB or molasses or BBM or BBE, and differences between means were tested using the least significant difference and an $\alpha$ level of $P<0.05$.

\section{RESULTS}

\section{Chemical Composition of Freshly Treated Bermudagrass Prior to Ensiling}

Table 1 shows the chemical composition of the bermudagrass forages prior to ensiling. The DM concentration of these forages was not affected by treatment $(P>$ $0.05)$, but the $\mathrm{pH}$ of those treated with $\mathrm{BB}$ and $\mathrm{BBE}$ was greater $(P<0.05)$ than that of the untreated forage. Forages treated with BBE also had higher $(P<0.05)$ $\mathrm{pH}$ than the others. Treatment with all additives except BB increased $(P<0.05)$ WSC concentration. Forages that were treated with molasses or BBM had particularly high WSC concentrations. Those treated with BBM had higher $(P=0.004)$ WSC concentrations than those treated with molasses alone. Ammonia N concentration was similar in additive-treated and untreated forages, except that BB-treated forages had higher ( $P$ $<0.05$ ) concentrations. Crude protein concentration was similar across treatments, except that lower concentrations were present in forages treated with BBM $(P<$ $0.05)$ than in molasses-treated or untreated forages. Additive treatment did not affect the ADF or NDF con- 
Table 1. Chemical composition of bermudagrass forages prior to ensiling (g/kg of DM or as stated).

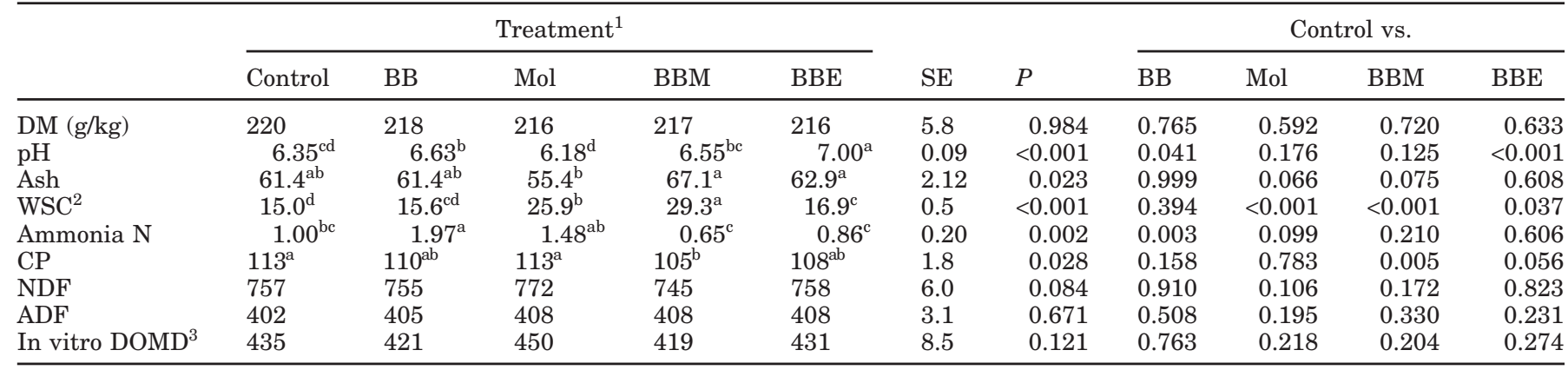

a,b,c Within a row, means without a common superscript letter differ $(P<0.05)$.

${ }^{1} \mathrm{BB}=$ mixture of Pediococcus pentosaceus 12455 at $1 \times 10^{5} \mathrm{cfu} / \mathrm{g}$ of fresh forage, Lactobacillus buchneri 40788 at $4 \times 10^{5} \mathrm{cfu} / \mathrm{g}$ of fresh forage, beta-glucanase, alpha-amylase, and xylanase; $\mathrm{Mol}=$ treated with $50 \mathrm{~g} / \mathrm{kg}$ of $\mathrm{DM}$ of molasses; $\mathrm{BBM}=\mathrm{BB}$ and molasses; and $\mathrm{BBE}=$ $\mathrm{BB}$ plus additional beta-glucanase, alpha-amylase, and xylanase.

${ }^{2} \mathrm{WSC}=$ Water-soluble carbohydrates.

${ }^{3} \mathrm{DOMD}=$ Digestible OM concentration.

centration or the in vitro digestible $\mathrm{OM}$ concentration of the forages.

\section{Chemical Composition of Bermudagrass Silages Ensiled for 2, 4, 7, and $30 \mathrm{~d}$}

Tables 2 and 3 show the chemical composition of the bermudagrass forages after different ensiling periods. The DM of the silages was not affected by treatment regardless of ensiling duration, except those ensiled for $30 \mathrm{~d}$. The BBM-treated silages that were ensiled for 30 $\mathrm{d}$ had higher $(P<0.05)$ DM concentrations than the corresponding untreated, BB-treated, or molassestreated silages. Only molasses-treated silages had higher $(P=0.048) \mathrm{DM}$ recovery than untreated silages ensiled for $2 \mathrm{~d}$. The BBM-treated silages had a similar tendency $(P=0.090)$. However, all the additives increased $(P<0.01)$ DM recovery when ensiled for 4,7 , or $30 \mathrm{~d}$. This increase was less pronounced $(P<0.01)$ in silages treated with $\mathrm{BB}$ than in those treated with molasses, BBM, or BBE at $4 \mathrm{~d}$ of ensiling, but the increase was similar $(P>0.05)$ across treatments at 7 and $30 \mathrm{~d}$ of ensiling.

On $\mathrm{d} 2$ and 4 after ensiling, WSC concentration was less $(P<0.05)$ in untreated silages than in silages treated with BB, molasses, or BBM. However, by d 7 after ensiling, only silages treated with molasses had greater $(P=0.028)$ WSC concentrations than untreated silages. By d 30 after ensiling, silages treated with $\mathrm{BB}$ and BBE had lower $(P<0.05)$ WSC concentration than

Table 2. Chemical composition of bermudagrass forages ensiled for 2 or $4 \mathrm{~d}$ (g/kg DM or as stated).

\begin{tabular}{|c|c|c|c|c|c|c|c|c|c|c|c|}
\hline & \multicolumn{5}{|c|}{ Treatment $^{1}$} & SE & $P$ & \multicolumn{4}{|c|}{ Control vs. } \\
\hline \multicolumn{12}{|c|}{ Forages ensiled for $2 \mathrm{~d}$} \\
\hline $\begin{array}{l}\text { DM recovery } \\
\mathrm{pH}\end{array}$ & ${ }_{5.35^{\mathrm{a}}}^{865}$ & $\begin{array}{l}918 \\
4.90^{\mathrm{bc}}\end{array}$ & $\begin{array}{l}979 \\
4.80^{c}\end{array}$ & $\begin{array}{l}961 \\
4.72^{\mathrm{c}}\end{array}$ & $\begin{array}{l}910 \\
4.98^{\mathrm{b}}\end{array}$ & $\begin{array}{c}36.9 \\
0.06\end{array}$ & $\begin{array}{r}0.265 \\
<0.001\end{array}$ & $\begin{array}{r}0.334 \\
<0.001\end{array}$ & $\begin{array}{r}0.048 \\
<0.001\end{array}$ & $\begin{array}{r}0.090 \\
<0.001\end{array}$ & 0.404 \\
\hline $\begin{array}{l}\mathrm{pH} \\
\mathrm{WSC}^{3}\end{array}$ & $\begin{array}{l}5.35^{\mathrm{a}} \\
4.2^{\mathrm{d}}\end{array}$ & $7.6^{\mathrm{bc}}$ & $9.1^{\mathrm{b}}$ & $12.8^{\mathrm{a}}$ & $5.1^{\mathrm{cd}}$ & $\begin{array}{l}0.06 \\
1.07\end{array}$ & $\begin{array}{l}<0.001 \\
<0.001\end{array}$ & $\begin{array}{r}<0.001 \\
0.043\end{array}$ & $\begin{array}{r}<0.001 \\
0.007\end{array}$ & $\begin{array}{l}<0.001 \\
<0.001\end{array}$ & $\begin{array}{r}<0.001 \\
0.546\end{array}$ \\
\hline Ammonia N & 6.19 & 4.61 & 5.42 & 5.33 & 3.50 & 0.70 & 0.132 & 0.0130 & 0.445 & 0.395 & 0.016 \\
\hline $\mathrm{DM}(\mathrm{g} / \mathrm{kg})$ & 223 & 224 & 221 & 224 & 224 & 3.5 & 0.968 & 0.848 & 0.688 & 0.824 & 0.911 \\
\hline DM recovery & $881^{\mathrm{c}}$ & $955^{\mathrm{b}}$ & $994^{\mathrm{a}}$ & $1000^{\mathrm{a}}$ & $990^{\mathrm{a}}$ & 8.20 & $<0.001$ & $<0.001$ & $<0.001$ & $<0.001$ & $<0.001$ \\
\hline $\mathrm{pH}$ & $5.61^{\mathrm{a}}$ & $4.81^{\mathrm{bc}}$ & $4.58^{\mathrm{d}}$ & $4.67^{\mathrm{cd}}$ & $4.96^{\mathrm{b}}$ & 0.06 & $<0.001$ & $<0.001$ & $<0.001$ & $<0.001$ & $<0.001$ \\
\hline WSC & $4.3^{\mathrm{c}}$ & $7.2^{\mathrm{b}}$ & $8.9^{\mathrm{a}}$ & $8.4^{\mathrm{a}}$ & $4.5^{\mathrm{c}}$ & 0.4 & $<0.001$ & $<0.001$ & $<0.001$ & $<0.001$ & 0.647 \\
\hline Ammonia $\mathrm{N}$ & 8.61 & 6.53 & 4.99 & 5.61 & 4.97 & 1.23 & 0.246 & 0.250 & 0.056 & 0.105 & 0.055 \\
\hline
\end{tabular}

a,b,c,d Within a row, means without a common superscript letter differ $(P<0.05)$.

${ }^{1} \mathrm{BB}=$ mixture of Pediococcus pentosaceus 12455 at $1 \times 10^{5} \mathrm{cfu} / \mathrm{g}$ of fresh forage, Lactobacillus buchneri 40788 at $4 \times 10^{5} \mathrm{cfu} / \mathrm{g}$ of fresh forage, beta-glucanase, alpha-amylase, and xylanase; Mol = treated with $50 \mathrm{~g} / \mathrm{kg}$ of DM of molasses; $\mathrm{BBM}=\mathrm{BB}$ and molasses; and $\mathrm{BBE}=$ BB plus additional beta-glucanase, alpha-amylase, and xylanase.

${ }^{2}$ Expressed as g/kg.

${ }^{3} \mathrm{WSC}=$ Water-soluble carbohydrates. 
ADDITIVES FOR BERMUDAGRASS

Table 3. Chemical composition of bermudagrass forages ensiled for 7 or $30 \mathrm{~d}$ (g/kg of DM or as stated).

\begin{tabular}{|c|c|c|c|c|c|c|c|c|c|c|c|}
\hline & \multicolumn{5}{|c|}{ Treatment $^{1}$} & $\mathrm{SE}$ & $P$ & \multicolumn{4}{|c|}{ Control vs. } \\
\hline \multicolumn{12}{|c|}{ Forages ensiled for $7 \mathrm{~d}$} \\
\hline DM recovery ${ }^{2}$ & $897^{\mathrm{b}}$ & $964^{\mathrm{a}}$ & $991^{\mathrm{a}}$ & $988^{\mathrm{a}}$ & $980^{\mathrm{a}}$ & 12.4 & $<0.001$ & 0.002 & $<0.001$ & $<0.001$ & $<0.001$ \\
\hline $\mathrm{pH}$ & $5.50^{\mathrm{a}}$ & $4.70^{\mathrm{bc}}$ & $4.53^{\mathrm{c}}$ & $4.67^{\mathrm{bc}}$ & $4.84^{\mathrm{b}}$ & 0.05 & $<0.001$ & $<0.001$ & $<0.001$ & $<0.001$ & $<0.001$ \\
\hline $\mathrm{WSC}^{3}$ & 4.2 & 4.8 & 6.7 & 5.8 & 4.8 & 0.7 & 0.159 & 0.564 & 0.028 & 0.135 & 0.565 \\
\hline Ammonia $\mathrm{N}$ & $12.43^{\mathrm{a}}$ & $6.00^{\mathrm{b}}$ & $6.94^{\mathrm{b}}$ & $4.4^{\mathrm{b}}$ & $3.85^{\mathrm{b}}$ & 1.27 & 0.003 & 0.003 & 0.009 & $<0.001$ & $<0.001$ \\
\hline $\mathrm{DM}(\mathrm{g} / \mathrm{kg})$ & $214^{\mathrm{b}}$ & $213^{b}$ & $218^{\mathrm{b}}$ & $231^{\mathrm{a}}$ & $223^{\mathrm{ab}}$ & 3.8 & 0.036 & 0.855 & 0.534 & 0.009 & 0.147 \\
\hline $\mathrm{DM}$ recovery & $833^{\mathrm{b}}$ & $941^{\mathrm{a}}$ & $968^{\mathrm{a}}$ & $973^{\mathrm{a}}$ & $976^{\mathrm{a}}$ & 19.6 & $<0.001$ & 0.002 & $<0.001$ & $<0.001$ & $<0.001$ \\
\hline $\mathrm{pH}$ & $4.93^{\mathrm{a}}$ & $4.47^{\mathrm{c}}$ & $4.63^{\mathrm{abc}}$ & $4.80^{\mathrm{ab}}$ & $4.60^{\mathrm{bc}}$ & 0.10 & 0.049 & 0.007 & 0.052 & 0.372 & 0.038 \\
\hline WSC & $5.2^{\mathrm{a}}$ & $3.5^{\mathrm{b}}$ & $4.8^{\mathrm{a}}$ & $5.0^{\mathrm{a}}$ & $3.5^{\mathrm{b}}$ & 0.24 & $<0.001$ & $<0.001$ & 0.214 & 0.451 & $<0.001$ \\
\hline Ammonia $\mathrm{N}$ & 10.14 & 7.65 & 9.12 & 8.30 & 9.87 & 1.22 & 0.588 & 0.175 & 0.567 & 0.308 & 0.878 \\
\hline
\end{tabular}

a,b,c Within a row, means without a common superscript letter differ $(P<0.05)$.

${ }^{1} \mathrm{BB}=$ mixture of Pediococcus pentosaceus 12455 at $1 \times 10^{5} \mathrm{cfu} / \mathrm{g}$ of fresh forage, Lactobacillus buchneri 40788 at $4 \times 10^{5} \mathrm{cfu} / \mathrm{g}$ of fresh forage, beta-glucanase, alpha-amylase, and xylanase; Mol = treated with $50 \mathrm{~g} / \mathrm{kg}$ of DM of molasses; $\mathrm{BBM}=\mathrm{BB}$ and molasses; and $\mathrm{BBE}=$ $\mathrm{BB}$ plus additional beta-glucanase, alpha-amylase, and xylanase.

${ }^{2}$ Expressed as $\mathrm{g} / \mathrm{kg}$.

${ }^{3} \mathrm{WSC}=$ Water-soluble carbohydrates.

untreated silages, while those treated with molasses or BBM had concentrations similar $(P>0.05)$ to the untreated silages.

The $\mathrm{pH}$ of additive-treated silages was lower $(P<$ 0.05 ) than that of untreated silages after $2,4,7$, and $30 \mathrm{~d}$ of ensiling, except in molasses- and BBM-treated silages ensiled for $30 \mathrm{~d}$. Molasses treatment was more effective $(P=0.02)$ than $\mathrm{BB}$ and $\mathrm{BBE}$ treatment at decreasing the $\mathrm{pH}$ in silages ensiled for $4 \mathrm{~d}$. However, this trend did not continue subsequently.

Silages treated with BBE had lower $(P=0.016)$ ammonia $\mathrm{N}$ concentrations than untreated silages after 2 $\mathrm{d}$ of ensiling. The BBE and molasses treatments tended $(P<0.1)$ to have a similar effect after $4 \mathrm{~d}$ of ensiling. All additive-treated silages ensiled for 7 or $30 \mathrm{~d}$ had similar ammonia $\mathrm{N}$ concentrations, but those ensiled for $7 \mathrm{~d}$ had lower values $(P<0.01)$ than those of untreated silages.

\section{Chemical Composition of Bermudagrass Silages Ensiled for $60 \mathrm{~d}$}

The DM concentration averaged $210 \mathrm{~g} / \mathrm{kg}$ after $60 \mathrm{~d}$ of ensiling and was not affected $(P>0.05)$ by treatment application (Table 4). Dry matter recovery was lower $(P<0.001)$ in the untreated silage than in all of the additive-treated silages, which had similar values. Ash concentration was lower $(P=0.014)$ in molasses-treated silages than in the untreated silage. Silages treated with $\mathrm{BB}$ had lower $(P<0.05) \mathrm{pH}$ than all other silages, which had similar values. Silages treated with BBE also tended to have lower $(P=0.060) \mathrm{pH}$ than untreated silages. Residual WSC concentrations of silages treated with $\mathrm{BB}, \mathrm{BBM}$, and $\mathrm{BBE}$ were lower $(P<0.05)$ than those in the untreated silage. Molasses-treated silages had a similar tendency $(P=0.058)$. The BB-treated silages had lower $(P=0.020)$ residual WSC concentrations than molasses-treated silages and tended $(P=$ 0.058 ) to have lower concentrations than BBE-treated silages. The ammonia $\mathrm{N}$ concentrations of silages that were not treated or treated with BBM or BBE were particularly high. All additive-treated silages had lower $(P<0.01)$ ammonia $\mathrm{N}$ concentrations than untreated silages, but those treated with $\mathrm{BB}$ or molasses had lower $(P<0.001)$ concentrations than those treated with $\mathrm{BBM}$ and $\mathrm{BBE}$. The values for BB-treated forages also tended to be lower $(P=0.069)$ than those in molassestreated silages when expressed as $\mathrm{g} / \mathrm{kg}$ of total N. Untreated silages had lower $(P<0.01) \mathrm{CP}$ concentrations than BB- and molasses-treated silages. In addition, BBtreated silages had higher $(P<0.05) \mathrm{CP}$ concentrations than BBM- and BBE-treated silages. Molasses-treated silages had more $(P<0.05) \mathrm{CP}$ than $\mathrm{BBE}$-treated silages and tended to have more $(P=0.094) \mathrm{CP}$ than BBMtreated silages. The NDF concentration of BBM-treated silages was lower $(P=0.042)$ than that of untreated silages and tended to be lower $(P<0.1)$ than those of BBand molasses-treated silages. The ADF concentraton of untreated silages was higher $(P<0.001)$ than that of BB-, molasses-, and BBM-treated silages and tended to be higher $(P=0.080)$ than that of BBE-treated silages. Acid detergent fiber concentration was also higher in BBE-treated silages $(P<0.05)$ than in the other additive-treated silages. Additive-treated silages had greater $(P<0.05)$ in vitro digestible OM concentration than untreated silages. Silages treated with BB or 
Table 4. Chemical composition of bermudagrass forages ensiled for $60 \mathrm{~d}$ (g/kg DM or as stated).

\begin{tabular}{|c|c|c|c|c|c|c|c|c|c|c|c|}
\hline & \multicolumn{5}{|c|}{ Treatment $^{1}$} & \multirow[b]{2}{*}{$\mathrm{SE}$} & \multirow[b]{2}{*}{$P$} & \multicolumn{4}{|c|}{ Control vs. } \\
\hline & Control & $\mathrm{BB}$ & Mol & $\mathrm{BBM}$ & $\mathrm{BBE}$ & & & $\mathrm{BB}$ & Mol & BBM & $\mathrm{BBE}$ \\
\hline $\mathrm{DM}(\mathrm{g} / \mathrm{kg})$ & 212 & 209 & 209 & 211 & 209 & 3.3 & 0.971 & 0.596 & 0.596 & 0.873 & 0.633 \\
\hline $\mathrm{DM}$ recovery $(\mathrm{g} / \mathrm{kg})$ & $867^{\mathrm{b}}$ & $969^{\mathrm{a}}$ & $968^{\mathrm{a}}$ & $952^{\mathrm{a}}$ & $956^{\mathrm{a}}$ & 10.2 & $<0.001$ & $<0.001$ & $<0.001$ & $<0.001$ & $<0.001$ \\
\hline Ash & $66.0^{\mathrm{a}}$ & $67.3^{\mathrm{a}}$ & $57.3^{\mathrm{b}}$ & $66.4^{\mathrm{a}}$ & $65.5^{\mathrm{a}}$ & 2.20 & 0.034 & 0.891 & 0.014 & 0.881 & 0.663 \\
\hline $\mathrm{pH}$ & $4.08^{\mathrm{a}}$ & $3.50^{\mathrm{b}}$ & $3.92^{\mathrm{a}}$ & $4.08^{\mathrm{a}}$ & $3.83^{\mathrm{a}}$ & 0.09 & 0.001 & $<0.001$ & 0.229 & 1.000 & 0.060 \\
\hline $\mathrm{WSC}^{2}$ & $5.9^{\mathrm{a}}$ & $3.8^{\mathrm{c}}$ & $5.0^{\mathrm{ab}}$ & $4.2^{\mathrm{bc}}$ & $4.7^{\mathrm{bc}}$ & 0.31 & 0.004 & $<0.001$ & 0.058 & 0.002 & 0.020 \\
\hline Ammonia N & $10.15^{\mathrm{a}}$ & $3.14^{\mathrm{d}}$ & $4.81^{\mathrm{cd}}$ & $7.15^{\mathrm{b}}$ & $6.25^{\mathrm{bc}}$ & 0.74 & $<0.001$ & $<0.001$ & $<0.001$ & 0.012 & 0.002 \\
\hline Ammonia $\mathrm{N}^{3}$ & $376^{\mathrm{a}}$ & $135^{\mathrm{c}}$ & $194^{\mathrm{c}}$ & $275^{\mathrm{b}}$ & $267^{\mathrm{b}}$ & 21.40 & $<0.001$ & $<0.001$ & $<0.001$ & 0.005 & 0.003 \\
\hline $\mathrm{CP}$ & $105^{\mathrm{c}}$ & $126^{\mathrm{a}}$ & $124^{\mathrm{ab}}$ & $114^{\mathrm{bc}}$ & $107^{\mathrm{c}}$ & 3.62 & 0.002 & $<0.001$ & 0.003 & 0.090 & 0.796 \\
\hline $\mathrm{ADF}$ & $494^{\mathrm{a}}$ & $470^{\mathrm{bc}}$ & $472^{\mathrm{bc}}$ & $467^{\mathrm{c}}$ & $488^{\mathrm{a}}$ & 2.1 & $<0.001$ & $<0.001$ & $<0.001$ & $<0.001$ & 0.080 \\
\hline NDF & 834 & 818 & 829 & 808 & 839 & 8.1 & 0.104 & 0.185 & 0.658 & 0.042 & 0.663 \\
\hline In vitro $\mathrm{DOMD}^{4}$ & $326^{\mathrm{d}}$ & $409^{\mathrm{ab}}$ & $423^{a}$ & $394^{\mathrm{b}}$ & $359^{\mathrm{c}}$ & 8.80 & $<0.001$ & $<0.001$ & $<0.001$ & $<0.001$ & 0.019 \\
\hline
\end{tabular}

a,b,c Within a row, means without a common superscript letter differ $(P<0.05)$.

${ }^{1} \mathrm{BB}=$ mixture of Pediococcus pentosaceus 12455 at $1 \times 10^{5} \mathrm{cfu} / \mathrm{g}$ of fresh forage, Lactobacillus buchneri 40788 at $4 \times 10^{5} \mathrm{cfu} / \mathrm{g}$ of fresh forage, beta-glucanase, alpha-amylase, and xylanase; $\mathrm{Mol}=$ treated with $50 \mathrm{~g} / \mathrm{kg}$ of DM of molasses; $\mathrm{BBM}=\mathrm{BB}$ and $\mathrm{molasses}$; and $\mathrm{BBE}=$ $\mathrm{BB}$ plus additional beta-glucanase, alpha-amylase, and xylanase.

${ }^{2} \mathrm{WSC}=$ Water-soluble carbohydrates.

${ }^{3}$ Expressed as $\mathrm{g} / \mathrm{kg}$ of total N.

${ }^{4}$ DOMD = Digestible OM concentration.

molasses also had greater $(P<0.05)$ in vitro digestible $\mathrm{OM}$ concentrations than those treated with BBE.

\section{Fermentation Indices and Microbial Composition of Bermudagrass Silages Ensiled for $60 \mathrm{~d}$}

The acetic acid concentrations of the silages were relatively high (Table 5). However, apart from lower $(P=0.037)$ concentrations in BBE-treated silages than in BB-treated silages, acetic acid concentration was not affected by treatment. Butyric acid was found in all silages except those treated with $\mathrm{BB}$ alone. Silages treated with $\mathrm{BB}$, molasses, and BBM had lower $(P<$ 0.001 ) butyric acid concentrations than untreated and BBE-treated silages. Molasses- and BB-treated silages had similar butyric acid concentrations, which were lower $(P<0.01)$ than those in BBM-treated silages. No isobutyric acid was found in the silages. Treatment application did not affect the lactic acid concentration of the silages; but, although minute quantities were present in those treated with BB, molasses, and BBM, none was found in the untreated and BBE-treated si-

Table 5. Fermentation characteristics, microbial composition, and aerobic stability of bermudagrass forages ensiled for $60 \mathrm{~d}$ (g/kg DM).

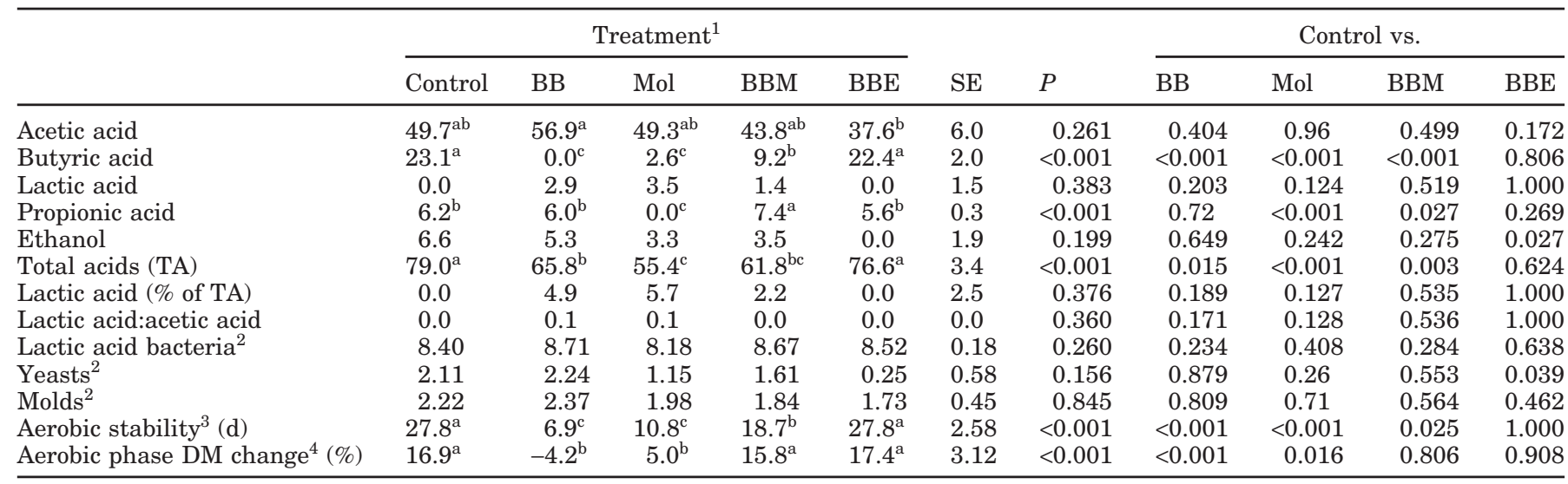

a,b,c Within a row, means without a common superscript letter differ $(P<0.05)$.

${ }^{1} \mathrm{BB}=$ mixture of Pediococcus pentosaceus 12455 at $1 \times 10^{5} \mathrm{cfu} / \mathrm{g}$ of fresh forage, Lactobacillus buchneri 40788 at $4 \times 10^{5} \mathrm{cfu} / \mathrm{g}$ of fresh forage, beta-glucanase, alpha-amylase, and xylanase; $\mathrm{Mol}=$ treated with $50 \mathrm{~g} / \mathrm{kg}$ of DM of molasses; $\mathrm{BBM}=\mathrm{BB}$ and molasses; and $\mathrm{BBE}=$ BB plus additional beta-glucanase, alpha-amylase, and xylanase.

${ }^{2}$ Expressed as log cfu/g of fresh forage.

${ }^{3}$ Aerobic stability is defined as the number of days before the silage temperature increased by $2{ }^{\circ} \mathrm{C}$ above ambient temperature.

${ }^{4}$ Change in the DM content of the silages during the 29-d aerobic phase. 
lages. No propionic acid was found in the molassestreated forages, which consequently had lower $(P<$ $0.05)$ propionic acid concentrations than the other silages. The BBM-treated silages had higher $(P<0.05)$ propionic acid concentrations than untreated, BB-, and BBE-treated silages. No ethanol was found in BBEtreated silages, which, therefore, had less $(P=0.027)$ ethanol than untreated silages and also tended to have less $(P=0.066)$ than BB-treated and untreated silages. Total acid concentration was higher $(P<0.05)$ in untreated and BBE-treated silages than in silages treated with BB, molasses, or BBM. The BB-treated silages had higher $(P=0.045)$ concentrations than molassestreated forages. The lactic-to-total acid and lactic-toacetic acid ratios were unaffected by treatment.

\section{Aerobic Stability and Microbial Counts of Bermudagrass Silages Ensiled for $60 \mathrm{~d}$}

Lactic acid bacteria counts tended to be lower $(P<$ 0.1 ) in molasses-treated silages than in BB- or BBMtreated silages (Table 5); otherwise, the counts were unaffected by treatment. Yeast counts were also unaffected by treatment. The only exceptions were lower $(P$ $<0.05$ ) counts in BBE-treated silages than in untreated or BB-treated silages. Mold counts were also unaffected by treatment.

All of the silages were stable for at least $6.9 \mathrm{~d}$ (Table 5). It took more than $27 \mathrm{~d}$ for untreated and BBEtreated silages to begin to deteriorate, but deterioration occurred after 6.9 and $10.8 \mathrm{~d}$ of aeration in BB-treated and molasses-treated silages, respectively. Therefore, BB-treated silages were less $(P<0.05)$ stable than those that were not treated or treated with BBM or BBE. There was an increase in DM content during the aerobic phase in all but the BB-treated silages, for which there was a decrease. This increase in DM content was greater $(P<0.05)$ in untreated, BBM-, and BBE-treated silages than in molasses- or BB-treated silages.

\section{DISCUSSION}

\section{Chemical Composition of Freshly Treated Bermudagrass}

The DM concentration at harvest was lower than that $(324 \mathrm{~g} / \mathrm{kg})$ reported for bermudagrass harvested at a similar maturity stage by Umana et al. (1991), although it approximated the range ( 230 to $280 \mathrm{~g} / \mathrm{kg}$ ) that Kunkle et al. (1988) found in their studies. The lower values in this study are largely attributable to the rainfall that occurred while the forages were being harvested. The 3 -h wilt and the use of the ventilation fan did not remove all of the moisture that had adhered to the forages. The low digestibility values and WSC concentrations of the bermudagrass are typical of tropical grasses (Catchpoole and Williams, 1969; Dawson, 1989; Umana et al., 1991). The increase in the $\mathrm{pH}$ of the pre-ensiled forages after treatment with the inoculants also agrees with previous results (Umana et al., 1991; Kung and Ranjit, 2001). Compared with the untreated forage, the higher WSC concentration of the molasses, BBM, and $\mathrm{BBE}$ treatments indicates that the objective of providing supplemental WSC in these treatments was achieved. However, the enzymes in BBE had not sufficiently hydrolyzed the forage cell walls to make the WSC concentration of forages treated with BBE greater than those for forages treated with $\mathrm{BB}$. The ammonia $\mathrm{N}$ concentration of the untreated forage was lower than that of Umana et al. (1991), revealing that less proteolysis occurred during wilting in this study.

\section{Chemical Composition of Bermudagrass Ensiled for 2, 4, 7, or $30 \mathrm{~d}$}

With a few exceptions, additive treatment was beneficial for reducing $\mathrm{pH}$, DM losses, and proteolysis in silages ensiled for 2 to $30 \mathrm{~d}$. However, there were notable differences between the effectiveness of the additives at the 4 ensiling periods. Molasses treatment reduced $\mathrm{pH}$ and increased DM recovery to a greater extent than BB treatment after $4 \mathrm{~d}$ of ensiling. This result suggests that the availability of readily fermentable carbohydrates may be a greater determinant of the initial fermentation rates in tropical grasses with low WSC levels than a desirable LAB population. However, the effectiveness of the $\mathrm{BB}$ treatment at later stages of the fermentation confirms that domination of the epiphytic microbial population of tropical grasses with homofermentative or facultative heterofermentative LAB is advantageous.

The residual WSC concentration of the untreated forage was less than that of forages treated with $\mathrm{BB}$, molasses, or BBM up to $7 \mathrm{~d}$ of ensiling, because of the supplemental WSC provided by the additives. However, at $30 \mathrm{~d}$ of ensiling, the WSC concentration of BB- and BBE-treated forages had declined below that of untreated forages. This reduction in WSC concentration is consistent with previous findings (Dawson, 1989; Kung and Ranjit, 2001; Adesogan and Salawu, 2002). It is attributable to the proliferation of $L$. buchneri, which is heterofermentative and, therefore, converts WSC to lactic acid, acetic acid, and ethanol. The WSC contribution from the molasses and BBM treatments ensured that forages treated with these additives maintained similar residual WSC concentrations to untreated forages for up to $30 \mathrm{~d}$ after they were ensiled. 


\section{Chemical and Microbial Composition and Aerobic Stability of Bermudagrass Ensiled for $60 \mathrm{~d}$}

Most of the beneficial effects of additive treatment that were observed in the earlier stages of fermentation persisted in forages ensiled for $60 \mathrm{~d}$. Nevertheless, there were notable differences between treatments in their effectiveness. All of the silages had $\mathrm{pH}$ values that were similar to or less than that (4.0) required for achieving stability during the fermentation (McDonald et al., 1991). Low silage $\mathrm{pH}$ and high lactic acid concentrations have been associated with decreased silage intake (Erdman, 1993). Although the $\mathrm{pH}$ of silages treated with $\mathrm{BB}$ was lower than that of the other silages, the BBtreated silages also had low lactic acid concentrations, which suggests that the concentration of free lactic acid in the silages treated with BB was relatively low; accordingly, it is unlikely that the low $\mathrm{pH}$ would adversely affect the intake of this silage. Proteolysis was most extensive in the untreated forages and least extensive in the BB-treated and molasses-treated forages. Although the molasses-treated forages continued to have residual WSC concentrations similar to the untreated forages after $60 \mathrm{~d}$ of ensiling, other treated forages had lower values than untreated silages. This shows that heterofermentative bacteria in these additives, such as the L. buchneri in BB, had fermented the WSC into acetic acid, ethanol, and lactic acid in the earlier stages of the fermentation. Therefore, although the treatments containing BB effectively curtailed proteolysis and DM losses, they did not prevent the fermentation of sugars in silages ensiled for $60 \mathrm{~d}$.

Based on improved DM recovery and reduced $\mathrm{pH}$ and proteolysis relative to untreated forages, the homofermentative $P$. pentosaceus effectively dominated the population of BB-treated forages and improved the quality of the fermentation. However, the acetate-producing effect of the heterofermentative L. buchneri in BB was matched by the epiphytic bacteria in the untreated forages. The similarity in the propionic acid concentrations of the BB- and BBE-treated and untreated forages suggests that the L. buchneri in such forages converted acetic acid into 1,2 propanediol, which can be converted into propionic acid by microbes such as Lactobacillus diolivorans (Driehuis et al., 2001). These concentrations were high enough to inhibit mold growth (Moon, 1983). The low ethanol concentrations and yeast and mold counts of all of the silages reflects the antimycotic properties of the VFA that were produced.

The improved aerobic stability of the untreated and $\mathrm{BBE}$-treated forages compared with the BB-treated forage was largely due to the presence of butyric acid, which was absent in the BB-treated forages. Butyric acid is more antimycotic than acetic acid (Higgins and
Brinkhaus, 1999), and its presence is typically associated with increased aerobic stability. However, the absence of lactic acid and the presence of relatively high levels of butyric acid in the untreated and BBE-treated silages suggest that undesirable secondary clostridial fermentation occurred in these forages. Therefore, although these forages were more stable, they contained less protein because of the extensive proteolysis that had occurred and would probably be less acceptable to livestock than forages treated with $\mathrm{BB}$ or molasses. The absence of butyric acid in the BB-treated forages, despite having similar LAB numbers to other treated forages, is noteworthy, as it highlights the effectiveness of this treatment alone at inhibiting the growth of clostridia despite the high temperature and moisture conditions at harvest that were conducive to their growth. The presence of butyric acid in the BBE-treated forages is surprising, as BBE only differed from BB because it had higher enzyme activities. The reason for the butyric acid production in BBE-treated forages is not clear. It may be related to observations that high levels of enzyme application are more detrimental to cell wall hydrolysis than low levels, possibly because excessive enzyme attachment to feed particles may restrict microbial attachment (Beauchemin et al., 2002).

It is important to note that despite the differences in aerobic stability between treatments, all the forages were stable for at least $6.9 \mathrm{~d}$. Therefore, even the BBtreated forage, which had the lowest aerobic stability, would be adequately preserved in the feed bunk for several days. Adesogan and Salawu (2004) observed that compared with controls, dual-purpose inoculants improved the fermentation, but not the aerobic stability, of intercrops of peas and wheat. In contrast, others (Driehuis et al., 2001; Weinberg et al., 2002; Filya, $2003 a, b)$ have found that such inoculants increased both fermentation and aerobic stability of wheat, corn, and sorghum silage. These different effects were attributed to differences in forage type and associated spoilage organisms (Adesogan and Salawu, 2004). Previous work has shown that aerobic deterioration in legumes is primarily associated with bacteria (McAllister et al., 1998). Because L. buchneri primarily curtails the growth of yeasts, it is unlikely to have affected the spoilage-causing bacteria in the legume-based intercrop. Also, forages that have high WSC concentrations, such as the ryegrass used by Driehuis et al. (2001), tend to benefit more from L. buchneri treatment because the fermentation of the untreated forage is predominantly homolactic. Such untreated forages have greater yeast counts and lower quantities of antimycotic acids than L. buchneri-treated forages, which are accordingly more stable. 
Whereas other treated forages had lower ADF concentrations and much greater in vitro digestibility values than the untreated forage, the BBE-treated forage, which contained additional fibrolytic enzymes, had a similar ADF concentration and a slightly greater in vitro digestibility. The higher indigestible fiber concentration of these forages might have been due to clostridial fermentation evidenced by greater butyric acid concentrations, which typically increase DM losses and deplete the concentration of soluble nutrients.

The hypothesis that the fermentation of bermudagrass silage would be enhanced by provision of supplemental WSC or appropriate LAB has been verified in this study. The absence of consistent additive effects of mixing BB with molasses or fibrolytic enzymes suggests that the WSC concentration and enzymatic activity of the BB inoculant are sufficient for improving the fermentation of tropical grasses. This contradicts the results of Umana et al. (1991), where mixing an inoculant with molasses improved the effectiveness of the inoculant at improving the fermentation of bermudagrass. Because BBM treatment was no better than the inoculant treatment at improving the fermentation, it may not be necessary to provide supplemental WSC when bermudagrass is treated with $\mathrm{BB}$. On the other hand, when bermudagrass is treated with molasses alone, it may not be necessary to dominate the epiphytic microbial population of bermudagrass with selected LAB. Further work is required to verify these findings.

This study also demonstrates that BB and molasses treatments can inhibit clostridial growth and the associated proteolysis and butyric acid accumulation, even under moist, humid conditions that are conducive to their proliferation. The untreated and BBE-treated silages were only more stable than BB- and molassestreated silages because they had high butyric concentrations and the associated rancid odor and low protein content. In contrast, BB- and molasses-treated forages had negligible quantities of butyric acid and relatively high protein concentrations and were stable for at least $6.9 \mathrm{~d}$, which is adequate for routine feeding operations.

The low lactic acid concentration of the silages mimics the findings of Umana et al. (1991) and is typical of tropical grass silages that have undergone heterolactic fermentation. Conversion of lactic acid into butyric acid by saccharolytic organisms such as Clostridium butyricum (McDonald et al., 1991) would have further depleted lactic acid levels. Because BB-treated forages and untreated forages had similar concentrations of acetic and propionic acids, it is not clear if BB treatment would have improved the stability of the silages in the absence of the rainfall-induced clostridial fermentation in the untreated silages. The accumulation of both of these acids during the heterofermentative degradation of lactic acid by L. buchneri is regarded as the primary reason why $L$. buchneri treatment improves aerobic stability. However, acetic acid is also the main end product of fermentation in tropical grasses (Bates et al., 1989), partly because of their low WSC concentration. The respective reasons for propionic acid accumulation in the untreated and BB-treated silages include clostridial fermentation, which is often accompanied by propionic acid production, and the action of $L$. diolivorans, which can convert 1,2 propanediol to propionic acid (Krooneman et al., 2002). This suggests that the BBtreated forage might have been more stable than the control silage if the latter had not been clostridial. Future studies should determine whether adding BB or molasses to bermudagrass harvested under dry conditions improves aerobic stability and animal performance.

\section{CONCLUSIONS}

This study shows that the fermentation and quality of low DM bermudagrass can be improved by treatment with BB or molasses. Both of these treatments resulted in the production of silages that were aerobically stable for at least $6.9 \mathrm{~d}$. The main advantage of using BB instead of molasses was a greater production of propionic acid and total acids and a tendency for decreased proteolysis. However, molasses treatment did result in higher residual WSC concentrations than BB. No consistent additive benefits were evident when the inoculant was mixed with molasses or fibrolytic enzymes.

\section{ACKNOWLEDGMENTS}

We gratefully acknowledge the assistance of John Funk and Nancy Wilkerson in conducting the analyses.

\section{REFERENCES}

Adesogan, A. T., and M. B. Salawu. 2002. The effect of different additives on the fermentation quality, aerobic stability and in vitro digestibility of pea/wheat bi-crop silages containing contrasting pea to wheat ratios. Grass Forage Sci. 57:25-32.

Adesogan, A. T., and M. B. Salawu. 2004. Effect of applying formic acid, heterolactic bacteria or homolactic and heterolactic bacteria on the fermentation of bi-crops of peas and wheat. J. Sci. Food Agric. 84:983-992.

Adesogan, A. T., M. B. Salawu, A. B. Ross, D. R. Davies, and A. E. Brooks. 2003. Effect of Lactobacillus buchneri, L. fermentum or Leuconostoc mesenteroides inoculants or a chemical additive on the fermentation, aerobic stability and nutritive value of crimped wheat grains. J. Dairy Sci. 86:1789-1796.

Association of Official Analytical Chemists. 1990. AOAC Official Method 990.03 Protein (Crude) in Animal Feed: Combustion Method. Page 18 in Official Methods of Analysis. AOAC, Washington, DC.

Bates, D. B., W. E. Kunkle, T. E. Dawson, A. Berthe, S. C. Denham, C. G. Chambliss, R. C. Cromwell, J. G. Wasdin, and D. L. Wakeman. 1989. Round bale silage-A forage harvesting alternative. Pages 
45-50 in Proc. 38th Annu. Beef Cattle Short Course, Univ. Florida, Gainesville.

Beauchemin, K. A., D. Colombatto, D. P. Morgavi, and W. Z. Yang. 2002. Use of exogenous fibrolytic enzymes to improve feed utilization by ruminants. J. Anim. Sci. 81(E. Suppl. 2):E37-E47.

Catchpoole, V. R., and T. Williams. 1969. The general pattern of fermentation in two subtropical grasses. J. Br. Grassl. Soc. 24.

Dawson, T. E. 1989. Effects of microbial inoculation on the quality of round bale bermudagrass silage. Ph.D. Diss., University of Florida, Gainesville.

Downes, F. P., and K. Ito. 2001. Acid-producing microorganisms. Pages 201-206 in Compendium of Methods for the Microbiological Examination of Foods. Am. Public Health Assoc., Waldorf, MD.

Driehuis, F., S. J. W. H. O. Elferink, and P. G. Van Wikselaar. 2001. Fermentation characteristics and aerobic stability of grass silage inoculated with Lactobacillus buchneri, with or without homofermentative lactic acid bacteria. Grass Forage Sci. 56:330-343.

Erdman, R. 1993. Silage fermentation characteristics affecting intake. Pages 210-219 in Proc. Silage Production from Seed to Animal. NRAES, Ithaca, NY.

Filya, I. 2003a. The effect of Lactobacillus buchneri and Lactobacillus plantarum on the fermentation, aerobic stability, and ruminal degradability of low dry matter corn and sorghum silages. J. Dairy Sci. 86:3575-3581

Filya, I. 2003b. The effect of Lactobacillus buchneri, with or without homofermentative lactic acid bacteria, on the fermentation, aerobic stability and ruminal degradability of wheat, sorghum and maize silages. J. Appl. Microbiol. 95:1080-1086.

Genstat V. 1997. Genstat V for Windows. Release 4.1. Lawes Agricultural Trust. IACR, Rothamsted, UK.

Higgins, C., and F. Brinkhaus. 1999. Efficacy of several organic acids against molds. J. Appl. Poult. Res. 8:480-487.

Krooneman, J., F. Faber, A. C. Alderkamp, S. J. H. W. Oude-Elferink, F. Driehuis, I. Cleenwerck, J. C. Swings, J. C. Gottschal, and M. Vancanneyt. 2002. Lactobacillus diolivorans sp. nov., a 1,2 propanediol-degrading bacterium isolated from aerobically stable maize silages. Int. J. Syst. Evol. Microbiol. 52:639-646.

Kung, L., and N. K. Ranjit. 2001. The effect of Lactobacillus buchneri and other additives on the fermentation and aerobic stability of barley silage. J. Dairy Sci. 84:1149-1155.
Kunkle, W. E., D. B. Bates, C. G. Chambliss, and R. P. Cromwell. 1988. Alternative forage storage-bale silage. Pages 31-41 in Proc. Dairy Herd Management Conf., University of Georgia, Athens.

McAllister, T. A., R. Feniuk, Z. Mir, P. Mir, L. B. Selinger, and K. J. Cheng. 1998. Inoculants for alfalfa silage: Effects on aerobic stability, digestibility and the growth performance of feedlot steers. Livest. Prod. Sci. 53:171-181.

McDonald, P., N. Henderson, and S. Heron. 1991. The Biochemistry of Silage. 2nd ed. Chalcombe Publications, Marlow, UK.

Ministry of Agriculture, Fisheries and Food. 1986. The Analysis of Agricultural Materials. Reference Book 427. HMSO, London.

Moon, N. J. 1983. Inhibition of the growth of acid tolerant yeasts by acetate, lactate and propionate and their synergistic mixtures. J. Appl. Bacteriol. 55:453-460.

Muck, R. E., and J. T. Dickerson. 1988. Storage temperature effects on proteolysis in alfalfa silage. Trans. ASAE 31:1005-1009.

Noel, R. J., and L. G. Hambleton. 1976. Collaborative study of a semiautomated method for determination of crude protein in animal feeds. J. AOAC 59:134-140.

Ranjit, N. K., and L. Kung. 2000. The effect of Lactobacillus buchneri, Lactobacillus plantarum, or a chemical preservative on the fermentation and aerobic stability of corn silage. J. Dairy Sci. 83:526-535.

Tilley, J. M. A., and R. A. Terry. 1963. A two stage technique for the in vitro digestion of forage crops. J. Br. Grassl. Soc. 18:104-111.

Tournas, V., M. E. Stack, P. B. Mislivec, H. A. Koch, and R. Bandler. 1999. Yeasts, molds and mycotoxins. Food and Drug Administration Bacteriological Analytical Manual. AOAC International, Gaithersburg, MD.

Umana, R., C. R. Staples, D. B. Bates, C. J. Wilcox, and W. C. Mahanna. 1991. Effects of a microbial inoculant and (or) sugarcane molasses on the fermentation, aerobic stability and digestibility of bermudagrass ensiled at two moisture contents. J. Anim. Sci. 69:4588-4601.

Van Soest, P. J., J. B. Robertson, and B. A. Lewis. 1991. Methods for dietary fiber, neutral detergent fiber and non-starch polysaccharides in relation to animal nutrition. J. Dairy Sci. 74:35683597.

Weinberg, Z. G., G. Ashbell, Y. Hen, A. Azrieli, G. Szakacs, and I. Filya. 2002. Ensiling whole-crop wheat and corn in large containers with Lactobacillus plantarum and Lactobacillus buchneri. J. Ind. Microbiol. Biotechnol. 28:7-11. 